\title{
The role of ecotones in the dehalogenation of chloroethenes in alluvial fan
}

\section{aquifers}

Jofre Herrero ${ }^{a}$, Diana Puigserver ${ }^{b}$, Ivonne Nijenhuis ${ }^{c}$, Kevin Kuntze ${ }^{c, d}$, Beth L. Parker ${ }^{e}$ and José M. Carmona ${ }^{\mathrm{a}}$

a Department of Minerology, Petrology and Applied Geology, Faculty of Earth Sciences,

The Water Research Institute (IdRA), University of Barcelona, C/ Martí Franquès sn, Barcelona, Spain

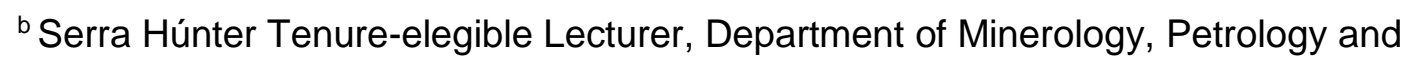
Applied Geology, Faculty of Earth Sciences, The Water Research Institute (IdRA), University of Barcelona, C/ Martí Franquès sn, Barcelona, Spain

${ }^{\mathrm{C}}$ Department of Isotope Biogeochemistry (ISOBIO), UFZ Centre for Environmental Research Leipzig-Halle, Permoserstr. 15; 04318 Leipzig, Germany

${ }^{d}$ Present address: Isodetect. Deutscher Platz 5b, 04103 Leipzig (Germany).

e School of Engineering, University of Guelph 50, Stone Road East, Guelph, Ontario, Canada N1G 2W1

Corresponding author. Tel.: +34 93 4021399; e-mail address: jofreherreroferran@ub.edu (J. Herrero).

\section{Abstract}

The presence of ecotones in transition zones between geological strata (e.g. layers of gravel and sand interbedded with layers of silt in distal alluvial fan deposits) in aquifers plays a significant role in regulating the flux of matter and energy between compartments. Ecotones are characterised by steep physicochemical and biological gradients and considerable biological diversity. However, the link between organic pollutants and degradation potential in ecotones has scarcely been studied. The aim of this study is to 
relate the presence of ecotones with the dehalogenation of chloroethenes. A field site was selected where chloroethene contamination occurs in a granular aquifer with geological heterogeneities. The site is monitored by multilevel and conventional wells. Groundwater samples were analysed by chemical, isotopic and molecular techniques. The main results were as follows: 1) two ecotones were characterised in the source area, one in the upper part of the aquifer and the second in the transition zone to the bottom aquitard, where the aged pool is located; 2) the ecotone located in the transition zone to the bottom aquitard has greater microbial diversity, due to higher geological heterogeneities; 3) both ecotones show the reductive dehalogenation of perchloroethylene and trichloroethylene; and 4) these ecotones are the main zones of the reductive dehalogenation of the pollutants, given the more reductive conditions at the centre of the plume. These findings suggest that ecotones are responsible for natural attenuation, where oxic conditions prevailed at the aquifer and bioremediation strategies could be applied more effectively in these zones to promote complete reductive dehalogenation.

\section{Keywords}

Ecotone, alluvial fan deposits, dehalogenation, chloroethenes, natural attenuation

\section{Acknowledgments}

We would like to acknowledge the Catalan Water Agency and the personnel of INTERFREN company in Figueres. We would also like to thank our colleagues of the Department of Isotope Biogeochemistry from Helmholtz Centre for Environmental Research (UFZ) in Germany. We are grateful to the Scientific-Technical Services personnel of the University of Barcelona for their help in analyzing the samples. We would like to highlight the institutions financing the research carried out within the following research projects: CTM, 2005-07824 and CGL, 2008-02164/BTE (Spanish Ministry of Education). 


\section{Introduction}

Chlorinated solvents, such as perchloroethylene (PCE) and trichloroethylene (TCE), are widely used as degreasing solvents and are among the most common industrial pollutants in developed countries across the world (Stroo et al., 2012). Spillages of chlorinated solvents migrate as dense non-aqueous phase liquids (DNAPLs), which constitute a source of pollution in the unsaturated zone and aquifers. The intrinsic characteristics of the sources are responsible for their long life and associated groundwater plumes (Pankow and Cherry, 1996), which are toxic even at low concentrations (Moran et al., 2006). Due to the risk of cancer as a result of exposure to PCE, TCE and vinyl chloride (VC), European guidelines on drinking water dictate that the sum of PCE and TCE must not exceed $10 \mu \mathrm{g} / \mathrm{L}$ and that the concentration of $\mathrm{VC}$ must not exceed $0.5 \mu \mathrm{g} / \mathrm{L}$ (Directive Council, 98/83/EC, 1998).

DNAPL mass distribution and plume morphology are strongly controlled by geological (Guilbeault et al., 2005), hydrogeological and biogeochemical heterogeneities (McMahon and Chapelle, 2008). These heterogeneities affect the distribution and development of microbial communities (Yang and McCarty, 2000) and their activity (Hakenkamp et al. 1994; Russell et al., 1994; Brockman and Murray, 2006). In the subsurface, ecotones are biogeochemical and microbial heterogenous zones of high richness and biological activity (Gosz, 1993) located in the contact zones between different habitats or ecosystems, e.g. the capillary oscillation fringe or contact surfaces between different lithological materials with textural contrasts ( Goldscheider et al., 2006; Puigserver et al., 2013; Griebler et al., 2014; Griebler and Avramov, 2015). At a site in La Pineda (Camp de Tarragona, NE Spain), Puigserver et al. (2013) demonstrated that the transition zone from a granular aquifer to a bottom aquitard in the plume constituted an ecotone where numerous biogeochemical processes coexisted. In this ecotone, layers of fine-grained sediments exhibited more developed microbial communities and greater microbial diversity than layers of coarser grained sediments. Groundwater flow through the more 
conductive layers in this transition zone supplied nutrients, contaminants and electron donors, leading to the biodegradation of the dissolved chlorinated solvents (Puigserver et al., 2020).

Chloroethenes may be recalcitrant (i.e. they are resistant to being broken down through chemical processes and last for several decades or longer in the environment, Pankow and Cherry, 1996). However, under anoxic conditions they can be transformed through reductive dehalogenation (Maymó-Gatell et al., 1997). During this process, chloroethenes are used as electron acceptors and tend to be less easily dehalogenated as the number of chlorine substituents decrease. This process takes place by sequential dehalogenation from PCE to TCE, to dichloroethylene (cisDCE, the most common metabolite; Pant and Pant, 2010), to VC and then to ethene or ethane (Vogel et al., 1987; Tiehm and Schmidt, 2011). Reduced conditions, from nitrate-reducing to methanogenic, are required to completely dehalogenate these compounds (Maymó-Gatell et al., 1995; Hoelen and Reinhard, 2004; Wei and Finneran, 2011; Němeček et al., 2017). Specifically, the reductive dehalogenation of PCE may take place under nitrate-reducing conditions (van der Zaan et al., 2010), TCE requires Mn- and Fe-reducing conditions, DCE isomers need sulphate-reducing conditions and VC occurs under methanogenic conditions (Chapelle and Bradley, 2003; Weatherill et al., 2018). Therefore, a significant amount of electron donors is needed to achieve substantial dehalogenation (Aulenta et al., 2007). Nevertheless, the reductive dehalogenation process can be partial or wholly inhibited in the presence of nitrate and sulphate, which are common co-contaminants in groundwater, because these compounds (as well as $\mathrm{Mn}^{4+}$ and $\mathrm{Fe}^{3+}$ ) compete as electron acceptors with chloroethenes. In addition to anaerobic dehalogenation pathways, the oxidative dehalogenation of TCE, isomers of DCE and VC, may also occur (Bradley and Chapelle, 2010; Dolinová et al., 2017).

Although changes in concentrations of contaminants, co-contaminants and metabolites help to identify the processes and microorganisms involved in degradation, 
compound-specific isotope analysis (CSIA) and specifically multi-element isotope analysis of chlorinated solvents, nitrate and sulphate has been applied as an efficient tool to: i) distinguish between sources of DNAPLs; ii) discern the processes responsible for the fate of chloroethenes, nitrate and sulphate in the environment (Aravena and Mayer, 2010; Hunkeler and Aravena, 2010); and iii) provide direct proof for the in situ biological degradation of these compounds (Aravena and Mayer, 2010). Generally, the oxidative dehalogenation of chloroethenes gives rise to lower isotopic enrichment than reductive dehalogenation (Hunkeler and Morasch, 2010). This is especially true for the oxidative dehalogenation of DCE isomers and VC. However, in some cases PCE and TCE may show small enrichment factors during reductive dehalogenation (Hunkeler and Morasch, 2010), which can easily lead to this process being underestimated.

The reductive dehalogenation of PCE and TCE to cisDCE can be carried out by a wide range of microorganisms, such as Dehalococcoides, Geobacter, Dehalobacter, Desulfitobacterium, Sulfurospirillum, Anaeromyxobacter, Desulfomonile, Desulfovibrio, Desulfuromonas and Dehalogenimonas spp. (Atashgahi et al., 2016; Nijenhuis and Kuntze, 2016; Dolinová et al., 2017). However, only Dehalococcoides spp. has been described as capable of the complete reductive dehalogenation of PCE to ethene (Maymó-Gatell et al., 1997; Zinder, 2016). Moreover, some oxidising microorganisms have been identified as able to oxidise chloroethenes to $\mathrm{CO}_{2}$, e.g. one-carbon compounds (Fitch et al., 1996; Semprini, 1995), ethene (Verce et al., 2001), propane (Malachowsky et al., 1994), propene (Reij and Kieboom, 1995), aromatic compounds such as toluene (Mars and Houwing, 1996; Shim et al., 2001), ammonium (Vannelli et al., 1990), isopropene (McCarty et al., 1994) and VC (Verce et al., 2002).

reductive dehalogenation processes in microbial systems. To characterise the microbial consortia in the presence of chlorinated solvents, terminal restriction fragment length polymorphism (T-RFLP) has been used efficiently in laboratory experiments (Flynn et 
al., 2000; Révész et al., 2006; Mészáros et al., 2013) and in field studies (Richardson et al., 2002; Lendvay et al., 2003; Macbeth et al., 2004; Rahm et al., 2006). As Dehalococcoides spp. only constitutes a small fraction in the microbial consortia, polymerase chain reaction (PCR) with specific primers targeting 16S rDNA or functional genes (RDase) is routinely used to determine their presence or absence in field samples (e.g. Nijenhuis et al., 2007; Abe et al., 2009; Hunkeler et al., 2011).

This study seeks to improve understanding of subsurface ecotones and their role in biogeochemical dehalogenation processes that affect the fate of groundwater dissolved chloroethenes. To this end, a site with a Mediterranean alluvial fan aquifer affected by PCE contamination was chosen and two working hypotheses were formulated: i) The contact zones between aquifers and aquitards constitute ecotones that play a key role in the dehalogenation of dissolved chloroethenes, and ii) Reductive dehalogenation can be favoured, especially in the centreline of a plume where a transition zone between the aquifer and the bottom aquitard exists.

To verify these hypotheses, hydrochemical analysis, isotope analysis of chloroethenes, nitrate and sulphate, T-RFLP and biomarkers of dehalogenation processes were used to evaluate in situ degradation and obtain different forms of evidence regarding the active processes.

\section{Site description}

Chloroethene contamination at the site has affected a confined aquifer comprising Pliocene prograding alluvial fan deposits (IGME, 1994; IGC, 1996). Groundwater pollution was detected in 1980, although it is not known when contamination occurred. The main contaminant is PCE, which was used as a degreaser at a nearby automotive plant. The source of contamination probably originated in the dumping of a PCE-free phase into a hollow next to the plant. Remediation measures have not been implemented, with the exception of the monitoring of natural attenuation. Groundwater 
contamination has resulted in concentrations of PCE that were still high in $2011(110 \mu \mathrm{M}$; (Puigserver et al., 2016). Furthermore, agricultural activities upgradient of the source have traditionally used manure as a fertiliser, which has led to diffuse nitrate pollution in the aquifers of the region.

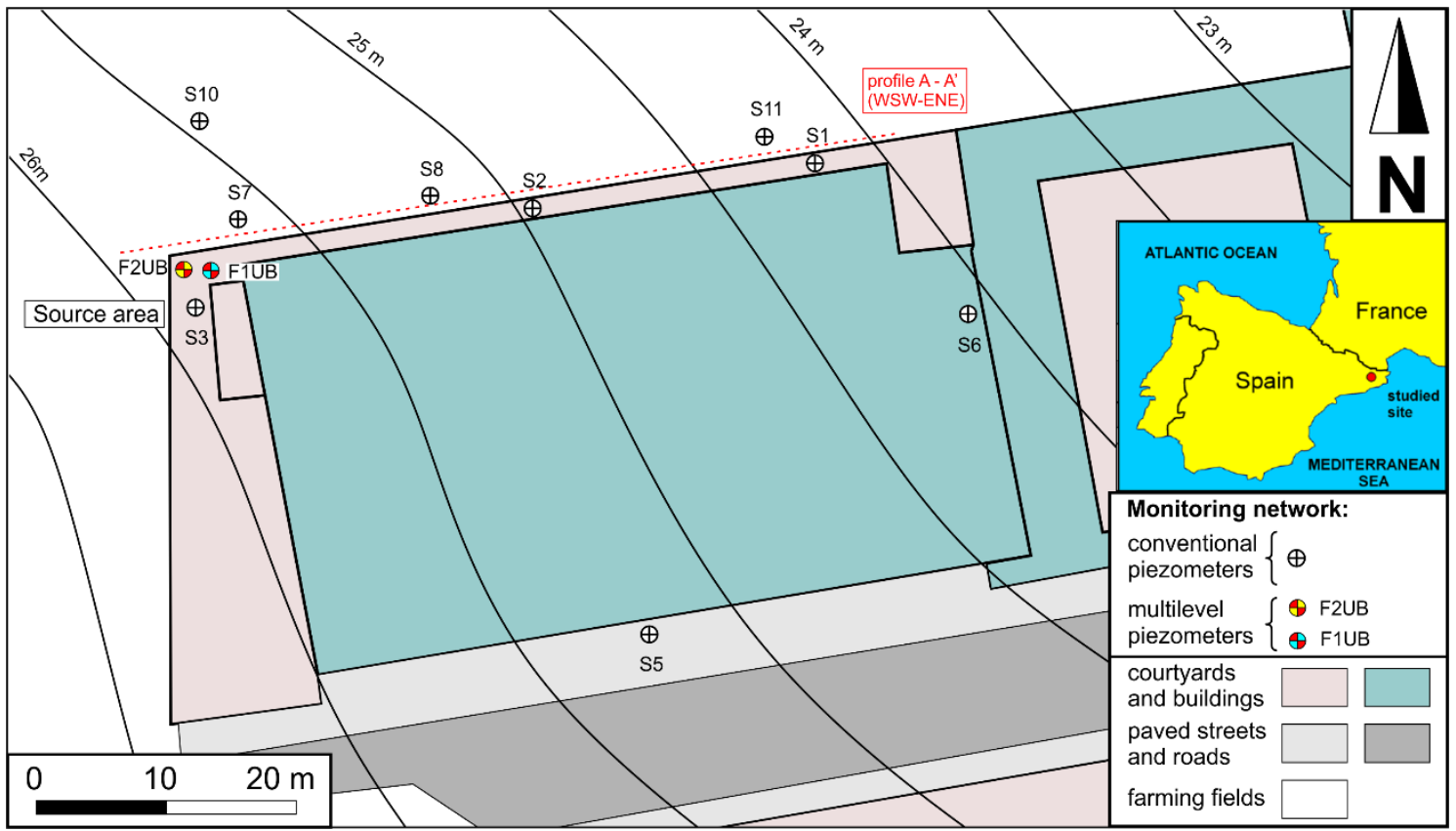

Fig. 1: Location map (Vilafant, Catalonia, Spain), piezometric map, monitoring network of conventional and multilevel piezometers F1UB and F2UB, and industrial buildings.

The monitoring network consists of 12 conventional piezometers installed by the Catalan Water Agency (ACA, Fig. 1). In addition, two boreholes (B-F1UB and B-F2UB, located at the source) were drilled by the Hydrogeology research group of the University of Barcelona in January 2011 and were subsequently equipped as multilevel piezometers (F1UB and F2UB, with five sampling ports each). Multilevel piezometers F1UB and F2UB and conventional piezometer S3 are located in the source area, while conventional piezometers S1, S2, S5, S6, S7, S8, S10 and S11 are located in the plume (Fig. 1). All conventional piezometers screen the whole aquifer until the basal aquitard, except S1 and S2 which only screen the first meter of the aquifer. 


\subsection{Hydrostratigraphic units distinguished in the subsurface}

A detailed core description of boreholes B-F1UB and B-F2UB was used to carry out the hydrostratigraphic analysis of the subsurface of the site (Puigserver et al., 2016). Accordingly, five hydrostratigraphic Pliocene units were distinguished from surface to bottom: 1) the unsaturated zone, which is made up of gravels and coarse, medium and fine sands; 2) the upper discontinuous thin aquitard, mostly consisting of clays and crossed by subvertical fractures and microfractures; 3 ) the upper part of the aquifer, where layers of gravels dominate over sands (of these layers, up to $27 \%$ have a siltyclayey to clayey matrix, with non-negligible contents of particulate organic matter) and there are some layers of fine sands and silts that also contain organic matter (hydraulic conductivities of the unit oscillate between 10 and $20 \mathrm{~m} /$ day); 4) the lower part of the aquifer, which comprises a transition zone to the bottom aquitard, which is made up of layers of sands and gravels with numerous interbedded sand and silt layers of limited lateral extension and variable amounts of particulate organic matter, whose hydraulic conductivities oscillate between 1 to $10 \mathrm{~m} /$ day; and 5) the bottom aquitard, which consists of fine laminar sands and silts crossed by a dense network of subvertical microfractures that interconnect millimetre-centimetre-scale interbedded layers of medium to coarse sands. Multilevel piezometers F1UB and F2UB and most of the conventional piezometers reach the top of the bottom aquitard.

Hydrostratigraphic units 1, 2 and 3 as a whole (unsaturated zone, upper aquitard and upper part of the aquifer) constitute the paleochannels that make up the prograding alluvial fans, while unit 4 (the transition zone) constitutes the sheet floods of the prograding system. Gravel paleochannels act as drainage lines, coinciding with the general flow towards the northeast, as shown in Fig. 1. The average fluctuation of the potentiometric level during the year is $1.5 \mathrm{~m}$ and the average gradient is 0.041 (Puigserver et al., 2016). 


\subsection{Biogeochemistry of the sediment cores}

Puigserver et al. (2016) characterised the distribution of chloroethenes in the porewater of fine sediments at the source (B-F1UB and B-F2UB) as well as of organic carbon, manganese, iron and microbial richness. High concentrations of chloroethenes were located immediately below the contact upper aquitard-upper part of the aquifer (depths of 4.80 and $4.51 \mathrm{~m}$ for B-F1UB and B-F2UB, respectively) and in the lower part of the aquifer, including the transition zone to the bottom aquitard, reaching concentrations of up to $112.86 \mu \mathrm{mol}$ PCE/L. Degradation haloes of PCE were identified with greater presence of TCE than cDCE.

Particulate organic matter, expressed as organic carbon fraction (\%), was generally higher in the fine-grained sediments, although significant declines in this parameter (with minimum values of $0.001 \%$ ) resulted from the consumption of organic matter as a donor of electrons in the biogeochemical processes identified (denitrification, reductive dehalogenation and sulphate reduction). Likewise, significant variations in manganese and iron were observed in these sediments (with maximum values of 33.9 and $667.0 \mu \mathrm{mol} / \mathrm{g}$, respectively). The redox conditions in the lower part of the aquifer reached those corresponding to the reduction of $\mathrm{Mn}$, Fe and sulphate. Microbial communities showed higher richness in the lithological contrasts at the top and bottom of the aquifer compared to nearby communities.

\section{Materials and methods}

\subsection{Groundwater sampling}

Groundwater samples were taken with an Eijkelkamp peristaltic pump with a Teflon pipe (with an external diameter of less than $9.5 \mathrm{~mm}$ ) in the case of Solinst-Canada multilevel well CMT system (7 ports) and an Integra Solinst Bladder pump with flow regulator in the case of the conventional wells. The maximum flow used during field parameter analysis 
and sampling was $0.2 \mathrm{~L} / \mathrm{min}$. Dissolved oxygen (DO), temperature $(\mathrm{T})$, redox potential (Eh), $\mathrm{pH}$ and electrical conductivity were determined by electrodes in a flow cell (Solinst ${ }^{\mathrm{TM}}$ ) in the field before taking any samples.

Aqueous samples of volatile organic compounds (VOCs) for concentration analysis were collected in $100 \mathrm{~mL}$ glass serum bottles (SUPELCO analytical). Aqueous samples for carbon isotope of VOCs and for total organic carbon dissolved in groundwater (TOC) analysis were collected in $120 \mathrm{~mL}$ amber screw cap bottles (SUPELCO analytical). Pyrex glass bottles were used for groundwater analysis of $\delta^{15} \mathrm{~N}_{\text {Nitrate, }} \delta^{18} \mathrm{O}_{\text {Nitrate }}$ and $\delta^{34} \mathrm{~S}_{\text {sulphate }}$ and $\delta^{18} \mathrm{O}_{\text {sulphate. Major }}$ anions and bicarbonate samples were filtered $(0,45 \mu \mathrm{m}$ pore size $)$ and collected in $150 \mathrm{~mL}$ translucent plastic bottles. Major cations and metals samples filtered $(0,45 \mu \mathrm{m}$ pore size $)$ and were collected in $14 \mathrm{~mL}$ transparent plastic vials. Samples were conserved at $4 \stackrel{\circ}{\circ} \mathrm{C}$. Molecular samples were filtered with $0.2 \mu \mathrm{m}$ pore (millipore, IsoporeTM membrane filters) and frozen below $-20^{\circ} \mathrm{C}$. In all cases, the sampling and conservation protocols were followed as presented in Puls and Barcelona (1996) and Johnston (2006).

\subsection{Analytical chemistry methods}

Water samples were analysed in the laboratories of the Scientific and Technological Centres of the University of Barcelona (ISO 9001:2015). Water samples were analysed by inductively coupled plasma optical emission (ICP-OES) for major cations. Anions were analysed by ion chromatography. Trace elements were analysed by inductively coupled plasma mass spectrometry (ICP-MS), while total organic carbon was analysed using the TOC analyser TOC-5000 (Shimadzu). VOCs in groundwater were analysed by gas chromatography-mass spectrometry (GC-MS). The determination of $\delta^{13} \mathrm{C}$ in VOCs was carried out by gas chromatography combustion isotope ratio mass spectrometry (GC-C-IRMS) in accordance with the protocol described by Palau et al. (2007). The pretreatment protocols used in order to determine the isotope content were those 
253 indicated in Dogramaci et al. (2001) for $\delta^{34} S_{\text {SulPhate }}$ and $\delta^{18} \mathrm{O}_{\text {Sulphate }}$ and in Silva et al.

254 (2000) and Fukada et al. (2003) for $\delta^{15} \mathrm{~N}_{\text {NITRATE }}$ and $\delta^{18} \mathrm{O}_{\text {NITRATE }}$ precipitates. These samples were analysed by isotope ratio mass spectrometry (IRMS).

\subsection{Molecular analysis}

Groundwater samples were analysed in the laboratoriesof the UFZ-Helmholtz Centre (Leipzig). DNA was extracted from the filters with the kit UltraClean Soil DNA (MoBio) following the manufacturer's protocol. Specific primers 582f (CTG TTG GAC TAG AGT ACA GC ) and 728r (GTG ACA ACC TAG AAA ACC GCC TT) and the PCR programme described in Löffler et al. (2000) were used to detect Dehalococcoides spp.

In order to perform T-RFLP, a 16S rDNA PCR was performed with 27fam (primer $27 f$ fluorescent, AGA GTT TGA TC(A/C) TGG CTC AG) and 1492r (GCYTACCTTGTTACGACTT) with the following PCR programme: an initial denaturation step at $95^{\circ} \mathrm{C}, 15 \mathrm{~min}$, followed by 30 cycles of denaturation at $94^{\circ} \mathrm{C}$ for 45 $\mathrm{s}$; annealing at $52^{\circ} \mathrm{C}$ for $45 \mathrm{~s}$; elongation at $72^{\circ} \mathrm{C}$ for $2 \mathrm{~min}$; last step at $72^{\circ} \mathrm{C}$ for $15 \mathrm{~min}$. The PCR product was purified with Kit Wizard ${ }^{\circledR}$ Genomic DNA (Promega). Each sample was digested in duplicates with restriction enzymes Haelll, Hhal and Mspl with the corresponding buffers. Subsequently, the sample was obtained as dried DNA.

The dried DNA was dissolved with Hi-Di ${ }^{\mathrm{TM}}$ Formamid (Applied Biosystems) with the standard GeneScan ${ }^{\mathrm{TM}} 500 \mathrm{ROX}^{\mathrm{TM}}$ and was analysed with 3100 Genetic Analyzer (Applied Biosystems). In order to obtain the length of the different fragments (labelled terminal restriction fragments or T-RFs), the software Peak scanner or Genemapper 3.7 Software (Applied Biosystems) was used.

\subsection{Treatment and interpretation of T-RFLP data}

The T-RFLP results were used to determine the microbial richness and the degree of development. Microbial diversity (richness) was assessed in terms of the number of 
restriction fragments $(\mathrm{RF})$ larger than $50 \mathrm{bp}$ and constituting more than $1 \%$ of the total area. Of the three different results (one for each restriction enzyme), the highest was taken as valid. According to Liu et al. (1997) and Marsh et al. (2000), actual microbial diversity is three or four times higher than the number of RF. The density of the microbial community (degree of development) was estimated by averaging the total area of the RF larger than $50 \mathrm{bp}$ and greater than $1 \%$ and then standardising in a scale from 0 to 10. The results of this parameter were treated as semi-quantitative data in accordance with Bruce (1997) and Liu et al. (1997). A cluster analysis using Ward's algorithm was performed to determine the similarity between microbial communities (Murtagh and Legendre, 2011).

From the results of the T-RFLP analysis focusing on three different restriction enzymes, the presence of microorganisms belonging to a specific ecological putative function was determined, important from the perspective of chlorinated solvent biodegradation (Table S1). The assignment of potential microorganisms was achieved using the phylogenetic assignment tool (PAT) described by Kent et al. (2003). The database of microorganisms was extended from those of the webpages of www.insilico.ehu.eus (Bikandi et al., 2004) and www.mica.ibest.uidaho.edu (Shyu et al., 2007).

Beyond the presence or absence of a particular species or family, the potential of a determined reaction event was assessed. Given their potential interactions with the dehalogenation processes, the occurrence of nitrification, metal oxidation $\left(\mathrm{Fe}^{2+}\right.$ and $\mathrm{Mn}^{2+}$ ), sulphide oxidation, methane oxidation, denitrification, metal reduction $\left(\mathrm{Fe}^{3+}\right.$ and $\mathrm{Mn}^{4+}$ ) and sulphate reduction were studied (Table S1). The occurrence of methanogenesis was not determined due to the need to perform a specific study of Archeobacteria and the lack of strong reducing conditions. 


\section{Results and discussion}

\subsection{Biogeochemical processes occurring in the source area}

\subsubsection{Degradation processes of redox-sensitive species, redox-dominant} conditions and redox zonation

A sequential redox zone configuration with depth is evident in the source area. Dominant redox conditions occur at each of these depths, mainly due to the concurrence of the following factors in the subsurface environment: i) particular geological and hydrogeological characteristics; ii) the bioavailability of different electron acceptors and nutrients; and iii) the existence of organic matter as a carbon source as well as energy for the microbial communities responsible for biogeochemical processes taking place (to which a putative ecological function is attributed).

The upper part of the aquifer (ports 3 of F1UB and F2UB multilevel piezometers) is mainly made up of thick layers of coarse-grained sediments (gravels and sands) with no matrix (see section 2.1). However, interbedded between these sediments at different depths, some thinner layers of gravels and sands with a silty-clayey and clayey matrix occur, although there are also layers formed by fine-grained sediments (fine sands and silts). High textural contrasts occur along the geological contact between the sediment layers with a fine matrix (and fine-grained sediments) and the gravel and sand layers with no matrix. These textural contrasts give rise to significant differences in hydraulic conductivity, resulting in much higher groundwater flow in gravels and sands with no matrix. Such flow along the geological contact of textural contrasts slowly dissolves the residual DNAPL-PCE at these depths (Puigserver et al., 2016), with dissolved PCE acting as an electron acceptor (Fig. 2, 1E and 2E). Furthermore, groundwater flow through coarse sediments without a matrix supplies other substances necessary for microorganisms from areas upgradient of the source, such as DO, nitrate and sulphate (Fig. 2, 1B,C,D and 2B,C,D), which together with oxidised minerals of $\mathrm{Mn}$ and $\mathrm{Fe}$ also 
act as electron acceptors (section 2.2). Moreover, groundwater flow provides nutrients and dissolved organic matter, expressed as TOC (Fig. 2, 1B and 2B). This TOC, in addition to the natural particulate organic matter in the gravel and sand layers with a fine matrix and in the fine-grained sediment layers (section 2.1), acts as a carbon source and electron donor for microorganisms living in the contrast zones. All these factors give rise to the higher development of the microbial communities (Fig. 2, 1G and 2G) undertaking the biogeochemical processes in the aquifer at the depths where these textural contrasts occur.

Denitrification processes in the presence of non-negligible concentrations of dissolved oxygen (Fig. 2, 1B and 2B) occur in ports 3 of F1UB and F2UB, as confirmed by the high concentrations of nitrite and isotopic values of $\delta^{15} \mathrm{~N}$ and $\delta^{18} \mathrm{O}$ for nitrate (Fig. 2, $1 \mathrm{C}$ and $2 \mathrm{C}$ ). Moreover, the presence of Mn-reduction processes was confirmed by a higher concentration of $\mathrm{Mn}^{2+}$ in ports 3 compared to ports 4 of F1UB and F2UB (Fig. 2, $1 \mathrm{~A}$ and $\mathrm{A})$.

Fe-reducing, Mn-reducing and sulphate-reducing bacteria (Table 1) in highly oxidant conditions prove that anaerobic reactions can be carried out by biofilms adapted to oxic conditions (Atlas and Bartha, 2002). Given the apparent contradiction between the presence of sulphate-reducing bacteria and the absence of evidence of sulphate reduction at the top of the upper part of the aquifer (constant concentration and absence of isotopic fractionation of sulphate, Fig. 2, 1D and 2D), it can be confirmed that sulphate reduction is not a constant process over time as it occurs only when biogeochemical conditions are favourable.

In the central part of the saturated zone (ports 4 and 5 of multilevel piezometers), which is predominated by medium to coarse gravel and sand, the flow velocity is higher. This favours a lower time of interaction between water and rock and consequently the conditions retain a more oxidant character over time (Fig. 2, 1A,B,C,D and 2A,B,C,D). In addition, TOC concentrations and organic carbon from the soil are very low, resulting in 
356 microbial communities remaining less developed (Fig. 2, 1G and 2G). Moreover, none 357 of the ecological putative functions studied have been detected (Table 1).

The decrease in hydraulic conductivity in the transition zone to the bottom aquitard is a consequence of the intrinsic characteristics of the material, as wells induced by the loss of porosity during DNAPL emplacement obstruct the flow through these materials (McWorther and Kueper, 1996). This hinders the oxygenation of the zone, which propitiates anaerobic conditions due to the presence of organic compounds, as shown in port 7 from multilevel piezometers F1UB and F2UB and piezometer S3 enrichment of nitrate (Fig. 2, 1C and 2C); 2) Mn- and Fe- reduction, due to the increase in $\mathrm{Mn}^{2+}$ and $\mathrm{Fe}^{2+}$ in groundwater (Fig. 2, $1 \mathrm{~A}$ and $2 \mathrm{~A}$ ), the presence of potential metal reducers and the decrease in $\mathrm{Mn}$ and Fe in sediments; and 3) sulphate reduction, given the decrease in sulphate concentration and the isotopic enrichment of sulphate (Fig. 2, 1D and 2D). Although we did not observe sulphate-reducing bacteria in the groundwater of the transition zone to the bottom aquitard (Table 1), a sulphate-reducing bacteria must be present in the sediment. 

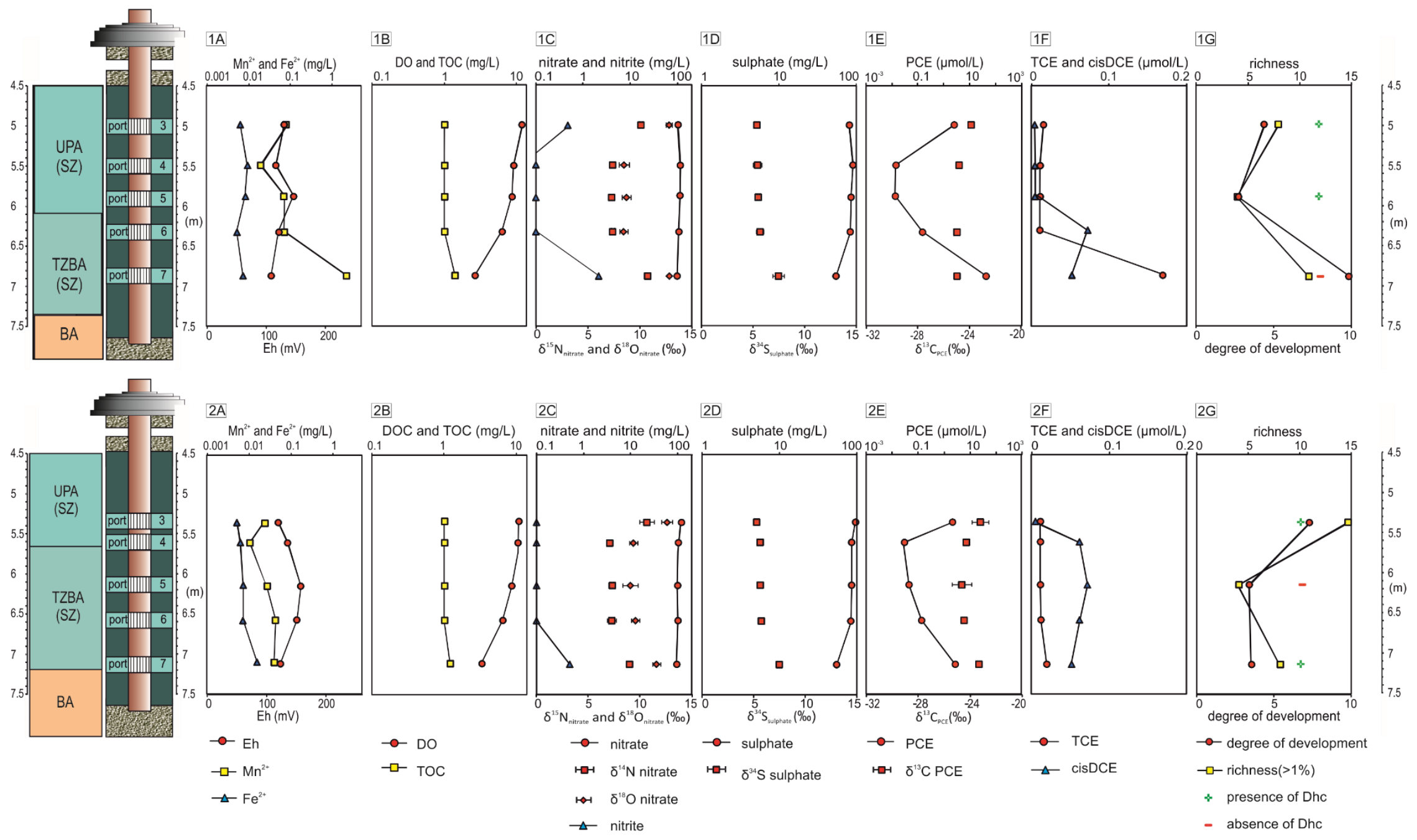
.Fig. 2: Depth profiles of $\mathrm{Eh}(\mathrm{mV})$ and concentrations of $\mathrm{Mn}^{2+}$ and $\mathrm{Fe}^{2+}(\mathrm{mg} / \mathrm{L})(1 \mathrm{~A}$ and $2 \mathrm{~A})$, $\mathrm{DO}$ and dissolved TOC (mg/L) (1B and $2 \mathrm{~B}), \mathrm{NO}_{3}{ }^{-}$and $\mathrm{NO}_{2}{ }^{-}(\mathrm{mg} / \mathrm{L})(1 \mathrm{C}$ and $2 \mathrm{C})$, $\mathrm{SO}_{4}{ }^{2-}(\mathrm{mg} / \mathrm{L})(1 \mathrm{D}$ and $2 \mathrm{D}), \mathrm{PCE}(\mu \mathrm{mol} / \mathrm{L})(1 \mathrm{E}$ and $2 \mathrm{E})$ and TCE and cisDCE $(\mu \mathrm{mol} / \mathrm{L})(1 \mathrm{~F}$ and $2 \mathrm{~F}$ ). Depth profiles of isotopic compositions $(\delta \%)$ of nitrate $(1 \mathrm{C}$ and $2 \mathrm{C}$ ), sulfate (1D and 2D) and PCE (1E and 2E). Depth profiles of richness and degree of development in the microbial communities, and presence or absence of Dehalococcoides spp (Dhc) (1G and 2G). SZ: saturated zone; UPA: Upper Part of the Aquifer; TZBA: Transition Zone to Basal Aquitard; BA: Basal Aquitard.

Table 1: Relationship of ecological putative function with absence (-) or presence $(+)$ of microorganism genera / operational taxonomic units. (++): two genera capable of performing an ecological putative function and / or a genus with a strict ecological function. $(+++)$ : three or more genera. See table S1 from supporting information for displayed data of each genus detected.

\begin{tabular}{|c|c|c|c|c|c|c|}
\hline & \multicolumn{4}{|c|}{ Group cluster A } & \multicolumn{2}{c|}{ Group cluster B } \\
\hline $\begin{array}{c}\text { Ecological putative } \\
\text { function }\end{array}$ & $\begin{array}{c}\text { Port 3 } \\
\text { (F1UB) }\end{array}$ & $\begin{array}{c}\text { Port 7 } \\
\text { (F1UB) }\end{array}$ & $\begin{array}{c}\text { Port 3 } \\
\text { (F2UB) }\end{array}$ & $\begin{array}{c}\text { Port 7 } \\
\text { (F2UB) }\end{array}$ & $\begin{array}{c}\text { Port 5 } \\
\text { (F1UB) }\end{array}$ & $\begin{array}{c}\text { Port 5 } \\
\text { (F2UB) }\end{array}$ \\
\hline $\begin{array}{c}\text { Oxidizers of Fe } \\
\mathrm{Mn}^{2+}\end{array}$ & $(+)$ & $(+++)$ & $(++)$ & $(+++)$ & $(-)$ & $(-)$ \\
\hline Oxidizers of sulfide & $(+)$ & $(+++)$ & $(-)$ & $(+++)$ & $(-)$ & $(-)$ \\
\hline Oxidizers of methane & $(++)$ & $(+)$ & $(++)$ & $(+++)$ & $(-)$ & $(-)$ \\
\hline $\begin{array}{c}\text { Reducers of Fe } \\
\text { Mnn }^{4+}\end{array}$ & $(++)$ & $(+)$ & $(++)$ & $(++)$ & $(-)$ & $(-)$ \\
\hline Sulfate-reducers & $(+++)$ & $(-)$ & $(++)$ & $(-)$ & $(-)$ & $(-)$ \\
\hline
\end{tabular}

\subsubsection{Reductive dehalogenation and oxidative degradation of chloroethenes}

At the top of the upper part of the aquifer (port 3 from multilevel piezometers F1UB and F2UB), the presence of both Dehalococcoides and a slightly fractionated PCE (Fig. 2, $1 E, G$ and $2 E, G)$ suggests that there is reductive dehalogenation of PCE when the biogeochemical conditions of the environment are favourable. Otherwise, the presence of methane-oxidising bacteria (Table 1) and the decrease in TCE and cisDCE in groundwater (Fig. 2, 1F and 2F) suggests oxidative biodegradation processes of TCE and cisDCE are taking place.

Dehalococcoides was detected in one of the multilevel wells in the central part of the aquifer (Fig. 2, $1 \mathrm{G}$ and 2G, port 5). However, the lack of metabolites of 
dehalogenation (Fig. 2, 1F and 2F) suggests that dehalogenation is not carried out. Therefore, the mobilisation of residual PCE has been produced by the physical mechanisms of progressive dissolution by groundwater flow without any degradation processes, due to the essentially oxidant conditions.

The reductive dehalogenation of PCE takes place in the transition zone to the bottom aquitard of F1UB. This process is potentially undertaken by Dehalococcoides spp., as confirmed by the isotope fractionation of PCE and the increase in TCE concentration in both groundwater (Fig. 2, 1E,F,G and 2E,F,G) and porewater (section 2.2)(Puigserver et al., 2016)(Puigserver et al., 2016)(Puigserver et al., 2016). Nevertheless, absence of Dehalococcoides spp. and no isotope fractionation of PCE has been detected in port 7 of F1UB (Fig. 2, 1E,G), suggesting that the high concentration of PCE is toxic to this species. Otherwise, there is the reductive dehalogenation of PCE, due to the high concentration of TCE in both groundwater (Fig. 2, 1F and 2E,F,G) and porewater (section 2.2). This process is probably carried out by the presence of a biofilm given their resistance to high toxicity (Harrison et al., 2007; Schaefer et al., 2010) and the presence of organohalide-respiring bacteria with minimal capacity to biodegrade PCE to cisDCE (Smidt and de Vos., 2004; Chang et al., 2011). Moreover, the fact that the isotope fractionation of PCE is minimal or non-existent in the zone of the transition zone to the bottom aquitard in F1UB can be attributed to a masking process via the continuous dilution of the source's DNAPL (Braeckevelt et al., 2012).

\subsubsection{Ecotone between upper discontinuous thin aquitard and upper part of the aquifer}

This ecotone is located just beneath the contact between the upper aquitard and the upper part of the aquifer (Figure 3). Its existence is supported by the existence of a microbial community with a greater degree of development and richness than the communities at the centre of the aquifer (Fig. 2, 1G and 2G). Moreover, there is evidence 
of the presence of microorganisms that potentially oxidise $\mathrm{Mn}, \mathrm{Fe}$, sulphide and methane and reduce Mn, Fe and sulphate (Table 1), alongside the presence of Dehalococcoides (Fig. 2, $1 \mathrm{G}$ and 2G).

Despite the oxic conditions observed in this interface (Fig. 2, 1B and 2B), there is evidence of $\mathrm{Mn}$ reduction, denitrification, reductive dehalogenation of PCE and oxidative dehalogenation of PCE metabolites (sections 4.1.1 and 4.1.2). In contrast to the situation in this zone, no reductive or oxidative process has been detected in the centre of the upper part of the aquifer.

\subsubsection{Ecotone in the transition zone to the bottom aquitard at the groundwater level}

The ecotone located in the transition zone to the bottom aquitard (Figure 3) is characterised by layers of sands and gravels with numerous interbedded sand and silt layers (section 2.1). This favours the existence of considerable microbial diversity and a good development of associated consortia in groundwater (Fig. 2, 1G and 2G) and sediments (section 2.2). In this ecotone, the presence of microorganisms that potentially oxidize $\mathrm{Mn}$, Fe, sulphide and methane and potentially reduce $\mathrm{Mn}$ and Fe has been detected (Table 1).

The transition zone to the bottom aquitard is a zone where reductive conditions predominate throughout the year, allowing the existence of denitrification, Mn and Fe reduction and sulphate reduction (section 4.1.1) as well as an important decrease in organic carbon content in the sediment (section 2.2).

The reductive dehalogenation of PCE to TCE occurs in the ecotone as well as to a lesser extent from TCE to cisDCE in groundwater (section 4.1.2), just as in porewater (section 2.2). This reductive dehalogenation is not exclusively carried out by Dehalococcoides spp. rather, other microorganisms are involved as well. 

developed than F2UB, evidenced by the greater richness and higher degree of development of the communities in F1UB (port 7 Fig. 2, 1G and 2G) as well as the additional potential of their ecological putative functions (port 7 Table 1). This fact is related to the presence of a matrix with less silt and clay content and less presence of PCE in the porewater. Despite differences in the lithology, distribution and concentration of PCE in the transition zone to the bottom aquitard of both boreholes, the same ecological putative function has been detected. This suggests that microbial communities and their putative function have a ubiquitous distribution along the ecotone, although there are differences at the centimetric scale.

\subsubsection{Comparative analysis between the ecotones}

In general, the ecotone of the transition zone to the bottom aquitard is better developed and presents superior richness than the ecotone of the upper part of the aquifer. This has been caused by greater textural contrasts and more stable conditions over time in the transition zone to the bottom aquitard compared to immediately below the contact between the upper aquitard and the upper part of the aquifer. Specifically, there is a direct relation between the number of textural and lithological changes per meter of thickness of upper part of the aquifer (2.31 and 5.80 for B-F1UB and B-F2UB, respectively, Puigserver et al., (2016)) and the transition zone to the bottom aquitard (6.74 and 4.38 for B-F1UB and B-F2UB, respectively, Puigserver et al., (2016)) and the richness of the microbial communities in the upper part of the aquifer ( 7 and 15 for $\mathrm{B}$ F1UB and B-F2UB, respectively, Figure 2, $1 \mathrm{G}$ and $2 \mathrm{G}$ ) and in the transition zone to the bottom aquitard (11 and 8 for B-F1UB and B-F2UB, respectively, Figure 2, 1 G and 2G). However, the existence of high concentrations of chloroethenes can be toxic to some microbial populations in groundwater (as has been shown in port 7 of F1UB) and favours the absence of species like Dehalococcoides (Sleep et al., 2006; Schaefer et al., 2010) and sulphate reducers (Yang and McCarty, 2002). By contrast, microbial populations in 
sediment show a smaller area of inhibition due to the influence of a high concentration of PCE, finding well-developed communities with greater richness $20 \mathrm{~cm}$ above the maximum of PCE (Puigserver et al., 2016).

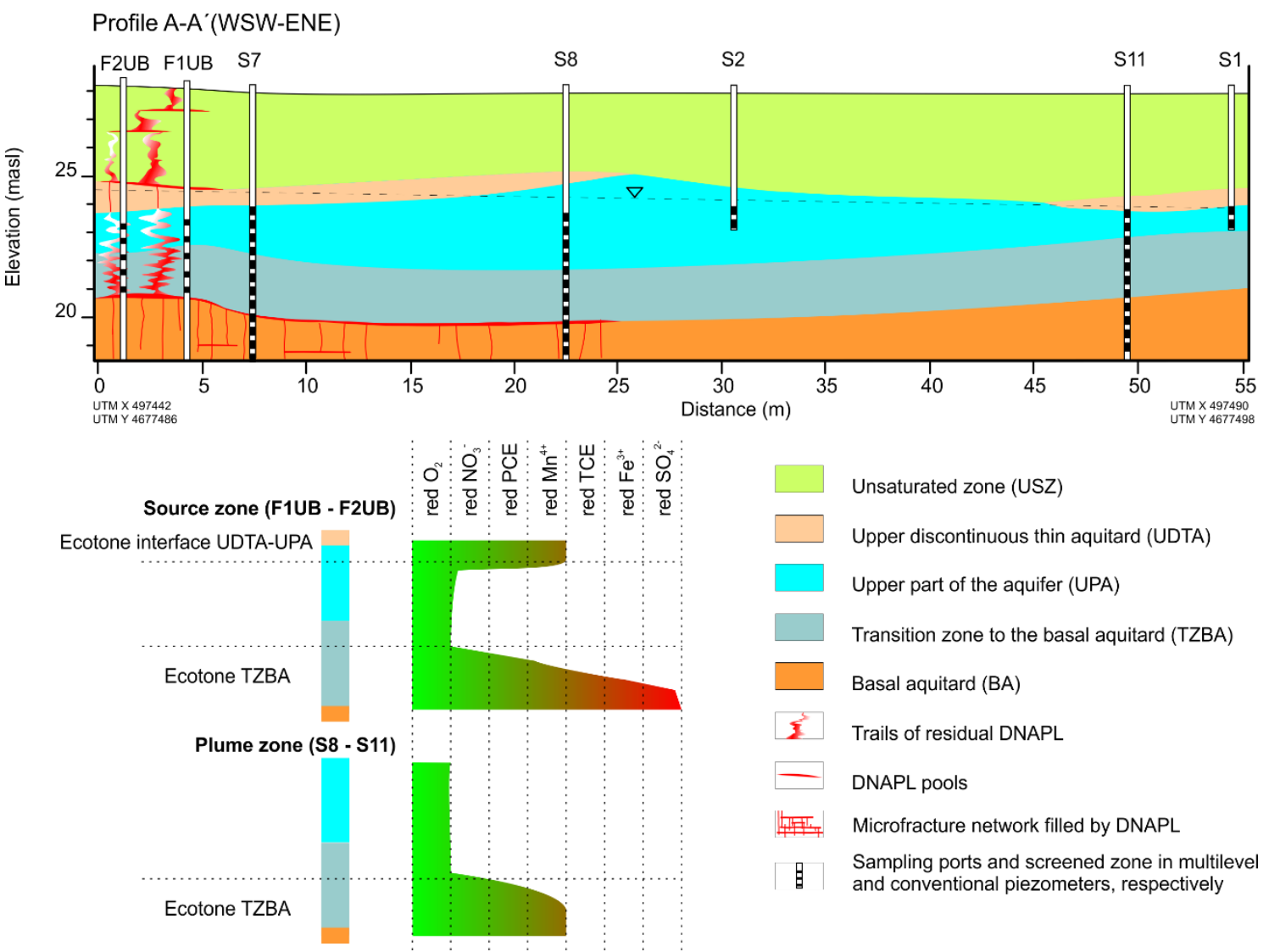

Fig. 3: Conceptual model of the location and length of the ecotones and the occurrence of redox-sensitive processes.

\subsection{Biogeochemical processes occurring in the plume}

\subsubsection{Redox zonation}

There is redox zonation in the plume, where the central part (S2, S8 i S11) shows oxic conditions, although there is also evidence of denitrification and manganese processes, while in the peripheral zones oxic conditions predominate (Table 2). Moreover, according to redox zonation at depths shown by multilevel wells in the source area, it should be 
more reducing conditions at the contrasts between confining aquitard and upper part of the aquifer and in the transition zone to bottom aquitard. Therefore, terminal electronacceptor processes such as denitrification, Mn reduction and reductive dehalogenation occur to a significant extent in these areas, while oxic conditions can be found at the centre of the aquifer.

No zonation of denitrifying process from the nitrate concentrations has been detected (Table 2). Nevertheless, isotopic data show isotopic fractionation in the centre of the plume (Table 2 and Fig. 4iError! No se encuentra el origen de la referencia.) with a ratio of $\delta^{15} \mathrm{~N} / \delta^{18} \mathrm{O}$ of 1.48 , higher than the ratios defined by other authors as regards denitrification, e.g. 0.48 and 0.77 (Böttcher et al., 1990 and Fukada et al., 2003), respectively, but in accordance with ratio between 1.0 to 2.0 defined by Kendall et al., (2008). Nevertheless, a ratio of $\delta^{15} \mathrm{~N} / \delta^{18} \mathrm{O}$ is in the same range (1.4 to 2.5) as Wexler et al. (2012), where denitrification was found to occur in a more complex scenario.

The presence of $\mathrm{Mn}^{2+}$ in the centre of the plume and the absence of this compound in the peripheral zone (Table 2) demonstrate that Mn reduction occurs exclusively in this area. Otherwise, neither Fe reduction nor sulphate reduction has been detected, evidenced by the absence of $\mathrm{Fe}^{2+}$ in groundwater and the low variability of sulphate concentrations along with the non-existence of this compound's isotopic fractionation.

Table 2: Hydrochemical data parameters in groundwater (field surveys of $5^{\text {th }}$ and $6^{\text {th }}$ of April 2012). ND = no data; ${ }^{*}=$ only detected in one piezometer. Xchloroethene (molar fraction).

\begin{tabular}{|c|c|c|c|}
\hline & $\begin{array}{c}\text { Peripheral zones of } \\
\text { the plume }\end{array}$ & $\begin{array}{c}\text { Central part of the } \\
\text { plume }\end{array}$ & Source area \\
\hline Piezometers & $\mathrm{S} 1, \mathrm{~S} 7$ and $\mathrm{S} 10$ & S2, S8 and S11 & $\begin{array}{l}\text { S3, port } 7 \text { of } F 1 \cup B \\
\text { and port } 7 \text { of } F 2 U B\end{array}$ \\
\hline $\mathrm{DO}(\mathrm{mg} / \mathrm{L})$ & 10.68 to 10.28 & 6.82 to 2.91 & 2.69 to $0.89 \mathrm{mg} / \mathrm{L}$ \\
\hline Nitrate $(\mathrm{mg} / \mathrm{L})$ & 165.6 to 62.2 & 123.0 to 26.3 & 155.4 to 93.4 \\
\hline$\delta^{15} \mathrm{~N}_{\text {nitrate }}(\%)$ & 6.9 to 7.2 & 7.3 to 11.1 & 7.3 to 10.7 \\
\hline$\delta^{18} \mathrm{O}_{\text {nitrate }}(\%)$ & 8.2 to 9.0 & 5.2 to 13.9 & 9.1 to 14.6 \\
\hline $\mathrm{Mn}^{2+}(\mathrm{mg} / \mathrm{L})$ & 0.02 to 0.07 & 0.01 to 0.11 & 0.04 to 2.15 \\
\hline$\sum$ chloroethenes $(\mu \mathrm{mol})$ & 0.3 to 3.3 & 1.0 to 21.6 & 44.0 to 104.0 \\
\hline Dominant Xchloroethenes & PCE & TCE & PCE \\
\hline
\end{tabular}




\begin{tabular}{|c|c|c|c|}
\hline$\delta^{13} \mathrm{C}_{\mathrm{PCE}}(\%)$ & -23.8 to -23.3 & -23.8 to -23.3 & -25.0 to -23.0 \\
\hline$\delta^{13} \mathrm{C}_{\text {TCE }}(\% \circ)$ & -27.1 to -26.7 & -27.4 to -22.0 & -22.8 to -22.1 \\
\hline$\delta^{13} \mathrm{C}_{\mathrm{CDCE}}(\%)$ & $\mathrm{ND}$ & -30.5 to -30.0 & $-22.1^{*}$ \\
\hline $\mathrm{TOC}(\mathrm{mg} / \mathrm{L})$ & 0.87 to 1.49 & 1.28 to 4.05 & 1.19 to 1.4 \\
\hline
\end{tabular}

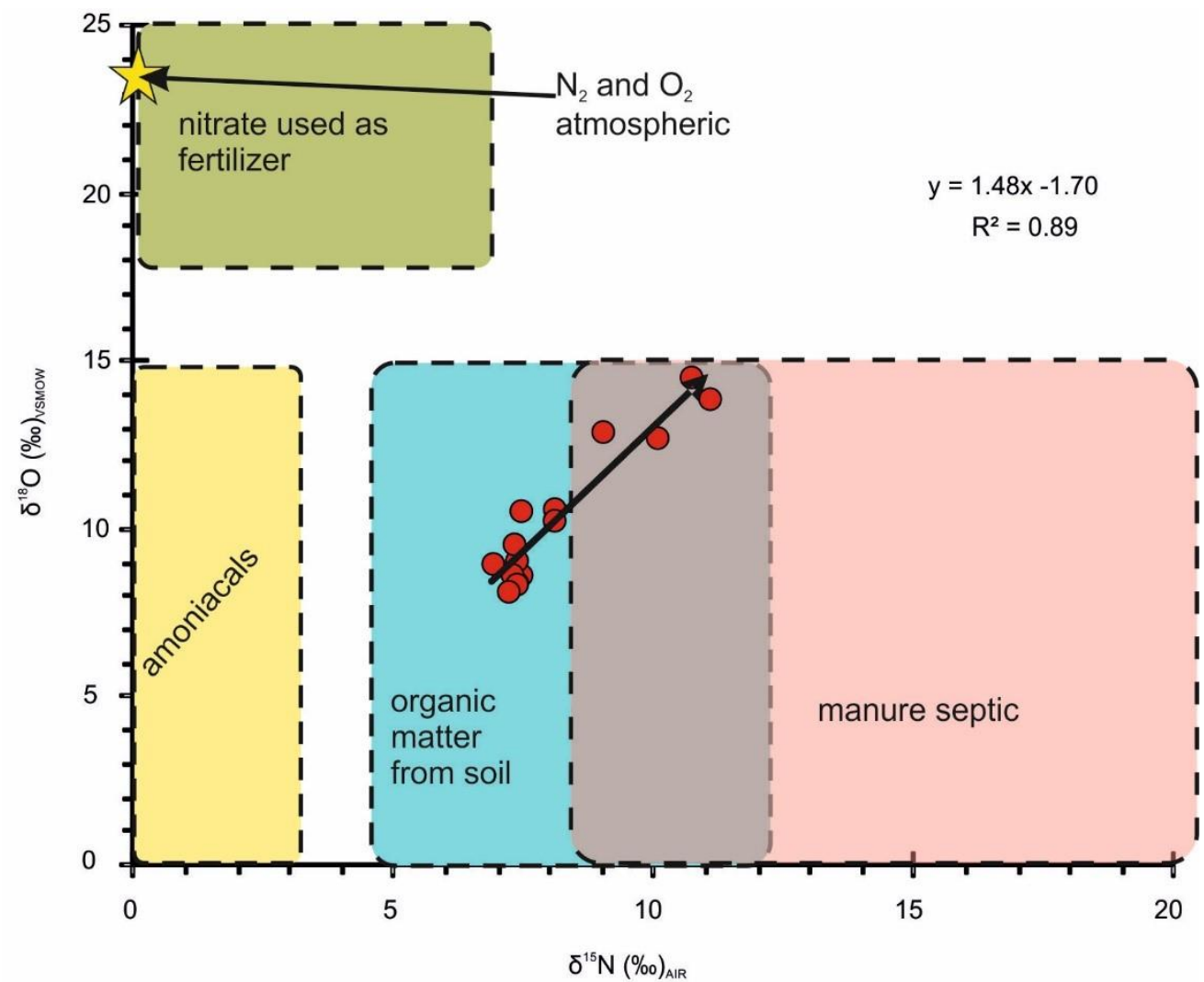

512 Fig. 4: Isotopic composition of the different sources of nitrate (adapted from Kendall and McDonnell, 1998). The results from the study zone (red dots) have been plotted with the trend line for denitrification.

\subsubsection{Reductive dehalogenation and oxidative degradation of chloroethenes}

In the central part of the plume there is a higher concentration of chloroethenes (Table 2 and Fig. 5) due to the domain of advective mechanisms (Feenstra et al., 1996).

519 Moreover, as has been observed in the source area, higher concentrations of chloroethenes are located in the lower part of the aquifer, due to the recalcitrance of DNAPL in the transition zone to the bottom aquitard. 
Redox zonation in the plume allows the biodegradation of PCE in micro-oxic environments of the transition zone to the bottom aquitard, from a metabolic pathway that produces low isotopic fractionation (Fig. 5). In addition, TCE is degraded by an anaerobic pathway (reductive dehalogenation) according to the presence of cisDCE (Fig. 5) and the punctual conditions of $\mathrm{Mn}$ reduction (Table 2).

The presence of cisDCE, the absence of $\mathrm{VC}$ and the less reductive conditions in the plume all suggest that complete reductive dehalogenation is not the main degradation process. Furthermore, the decrease in cisDCE in the central part of the plume under oxidising conditions can be attributed not only to the physical mechanisms of transport, but to aerobic biodegradation, as observed towards the upper part of the aquifer in the source area.

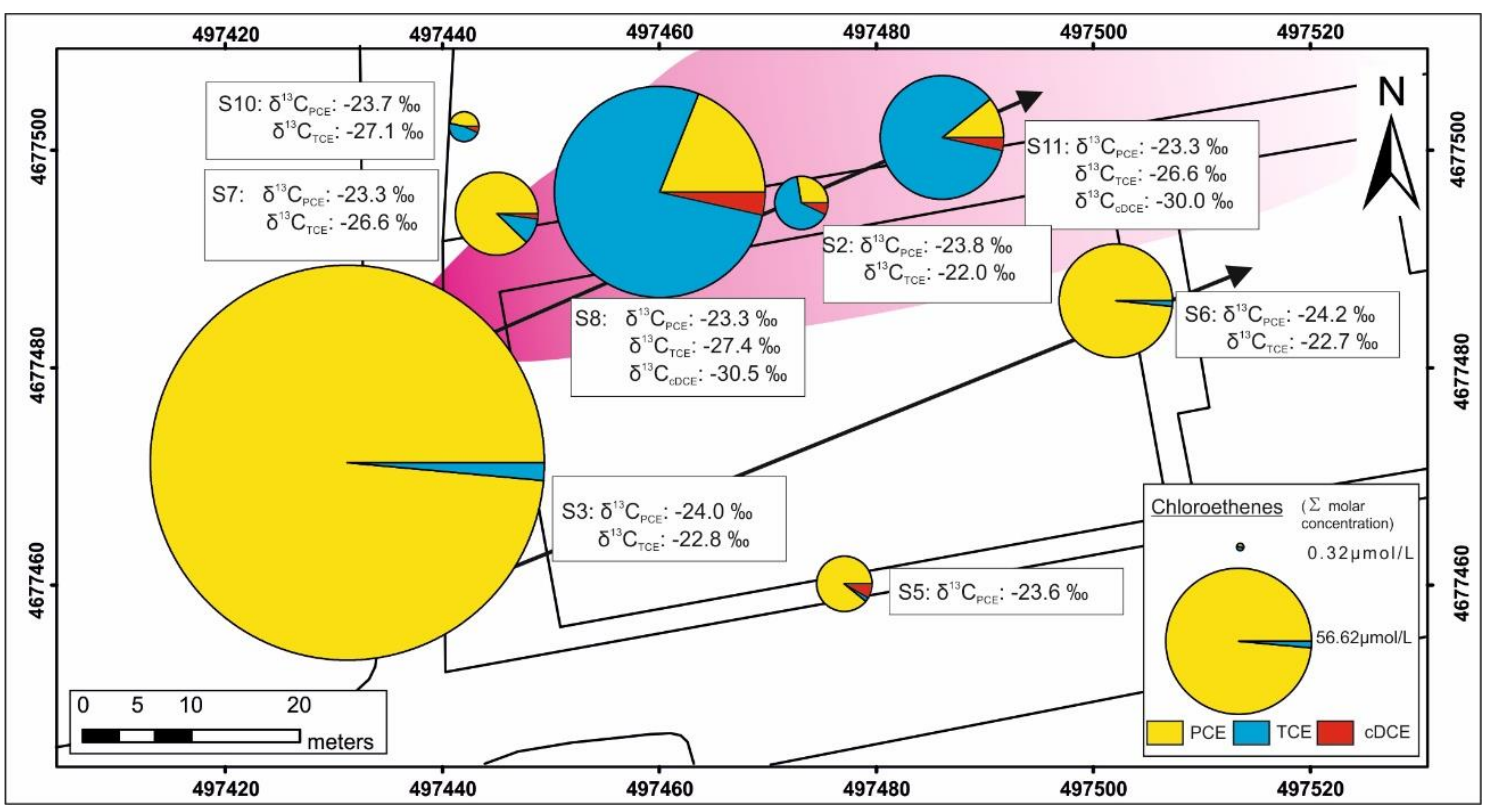

Fig. 5: Molar concentrations and isotopic composition of chloroethenes. Concentrations are represented as proportional circles to the sum of chloroethenes, with a minor value of $0.32 \mu \mathrm{mol} / \mathrm{L}$ and a maximum of $56.62 \mu \mathrm{mol} / \mathrm{L}$. Each square box shows the name of the sampling point and the isotopic composition of chloroethenes. Black arrows represent the general flow direction and the shaded area of pink represents the theoretical plume. 
4.2.3. Evidence of reductive dehalogenation in the plume due to the presence of the transition zone to the bottom aquitard

There is reductive dehalogenation of PCE and TCE in the centre of the plume area, even with oxic conditions, due to the presence of the transition zone (Fig. 3). This statement is evidenced by: 1) the presence of a transition zone to the bottom aquitard in all the areas occupied by the plume, suggesting that the microbial communities are welldeveloped, as has been seen in groundwater and in sediments; 2) anoxic reactions are occurring, e.g. denitrification and $\mathrm{Mn}$ reduction (Table 2); and 3) the reductive dehalogenation of PCE and TCE (Fig. 5), similarly observed in the transition zone to the bottom aquitard of the source area.

Otherwise, at the peripheral part of the plume and in the upper part of the aquifer, the dominance of aerobic conditions (Table 2) and the absence of metabolites (Fig. 5) suggest that even with the presence of a transition zone between the aquifer and the aquitard, the conditions for reductive dehalogenation to take place are lacking.

\section{Conclusions}

Two ecotones have been defined in the source area, one located in the upper part of the aquifer and the other located at the transition zone to the bottom aquitard. The microbial communities associated with the two ecotones are ultimately responsible for the biodegradation processes occurring in the source area. Reductive dehalogenation of PCE, oxidative dehalogenation of PCE metabolites, denitrification and $\mathrm{Mn}$ reduction occur in the ecotone in the upper part of the aquifer. In addition, reductive dehalogenation of PCE and TCE, oxidative dehalogenation of PCE metabolites, denitrification, $\mathrm{Mn}$ and Fe reduction and sulphate reduction all occur in the ecotone of the transition zone. Therefore, given the coexistence of different biogeochemical processes, these areas can be targeted to perform bioremediation strategies. 
In the source area, only limited biodegradation processes were identified within 567 the two ecotones. The absence of biodegradation processes beyond the two ecotones mainly owed to two factors: 1) the less reductive conditions of the zone, given the insufficient input of electron donors, the low amount of organic carbon in the sediment and the continuous input of nitrate; and 2) the low degree of development of the microbial communities in the upper part of the aquifer.

In spite of the oxic conditions of the plume, the existence of a transition zone allows anoxic biogeochemical processes to take place. Specifically, denitrification, $\mathrm{Mn}$ reduction and reductive dehalogenation of PCE and TCE occur. In relation, the same processes plus Fe reduction and sulphate reduction take place in the transition zone to the bottom aquitard in the source area. 
-Ethical Approval: not applicable

-Consent to Participate: not applicable

-Consent to Publish: not applicable

-Authors Contributions: All authors contributed to the study conception and design. Material preparation, data collection and analysis were performed by Jofre Herrero, Diana Puigserver and José Maria Carmona, except for the molecular data, that the data collection and analysis were performed by Jofre Herrero, Ivonne Nijenhuis and Kevin Kuntze. Beth L. Parker developed and supervised the sampling and analysis protocols and participated in the building of the conceptual model. The first draft of the manuscript was written by Jofre Herrero and all authors commented on previous versions of the manuscript. All authors read and approved the final manuscript.

Funding: This study was funded by projects CTM, 2005-07824 and CGL, 200802164/BTE (Spanish Ministry of Education).

-Competing Interests: the authors declare that they have no conflict of interest.

-Availability of data and materials: All data generated or analysed during this study are included in this published article [and its supplementary information files], except for the geochemical data, that could be found in Puigserver et al., 2016. The datasets used and analysed during the current study are available from the corresponding author on reasonable request. 


\section{References}

Abe, Y., Aravena, R., Zopfi, J., Parker, B., Hunkeler, D., 2009. Evaluating the fate of chlorinated ethenes in streambed sediments by combining stable isotope, geochemical and microbial methods. J. Contam. Hydrol. 107, 10-21. https://doi.org/10.1016/j.jconhyd.2009.03.002

Atashgahi, S., Lu, Y., Smidt, H., 2016. Overview of Known Organohalide-Respiring Bacteria-Phylogenetic Diversity and Environmental Distribution, in: OrganohalideRespiring Bacteria. Springer Berlin Heidelberg, Berlin, Heidelberg, pp. 63-105. https://doi.org/10.1007/978-3-662-49875-0_5

Atlas, R., Bartha, R., 2002. Interacciones entre poblaciones microbianas, in: Ecología Microbiana y Microbiología Ambiental.Pearson Educación SA, Madrid.

Aulenta, F., Pera, A., Rossetti, S., Petrangeli Papini, M., Majone, M., 2007. Relevance of side reactions in anaerobic reductive dechlorination microcosms amended with different electron donors. Water Res. 41, 27-38. https://doi.org/10.1016/j.watres.2006.09.019

Bikandi, J., San Millán, R., Rementeria, A., Garaizar, J., 2004. In silico analysis of complete bacterial genomes: PCR, AFLP-PCR and endonuclease restriction. Bioinformatics 20, 798-9. https://doi.org/10.1093/bioinformatics/btg491

Bradley, P.M., Chapelle, F.H., 2010. Biodegradation of chlorinated ethenes, in: In Situ Remediation of Chlorinated Solvent Plumes. Springer, pp. 39-67. https://doi.org/10.1007/978-1-4419-1401-9

Braeckevelt, M., Fischer, A., Kästner, M., 2012. Field applicability of Compound-Specific Isotope Analysis (CSIA) for characterization and quantification of in situ contaminant degradation in aquifers. Appl. Microbiol. Biotechnol. 1-21. 
Brockman, F.J., Murray, C.J., 2006. Subsurface microbiological heterogeneity: current knowledge, descriptive approaches and applications. FEMS Microbiol. Rev. 20, 231-247. https://doi.org/10.1111/j.1574-6976.1997.tb00311.x

Chapelle, F.H., Bradley, P.M., 2003. Redox conditions and the reductive/oxidative biodegradation of chlorinated ethenes in groundwater systems, in: Dehalogenation: Microbial Processes and Environmental Application. pp. 373-384.

Dogramaci, S.S., Herczeg, A.L., Schiff, S.L., Bone, Y., 2001. Controls on $\delta<$ sup> $34</$ sup $>$ S and $\delta<\sup >18</$ sup $>$ O of dissolved sulfate in aquifers of the Murray Basin, Australia and their use as indicators of flow processes. Appl. Geochemistry $16,475-488$.

Dolinová, I., Štrojsová, M., Černík, M., Němeček, J., Macháčková, J., Ševců, A., 2017. Microbial degradation of chloroethenes: a review. Environ. Sci. Pollut. Res. 24, 13262-13283. https://doi.org/10.1007/s11356-017-8867-y

Feenstra, S., Cherry, J.A., Parker, B.L., 1996. Conceptual models for the behavior of dense non-aqueous phase liquids (DNAPLs) in the subsurface, in: Dense Chlorinated Solvents and Other DNAPLs in Groundwater: History, Behavior, and Remediation. pp. 75-78.

Fitch, M.W., Speitel, G.E., Georgiou, G., 1996. Degradation of Trichloroethylene by Methanol-Grown Cultures of Methylosinus trichosporium OB3b PP358. Appl. Environ. Microbiol. 62, 1124-8.

Flynn, S.J., Löffler, F.E., Tiedje, J.M., 2000. Microbial community changes associated with a shift from reductive dechlorination of PCE to reductive dechlorination of cisDCE and VC. Environ. Sci. Technol. 34, 1056-1061.

Fukada, T., Hiscock, K.M., Dennis, P.F., Grischek, T., 2003. A dual isotope approach to 

identify denitrification in groundwater at a river-bank infiltration site. Water Res. 37, 3070-3078.

Goldscheider, N., Hunkeler, D., Rossi, P., 2006. Review: Microbial biocenoses in pristine aquifers and an assessment of investigative methods. Hydrogeol. J. 14, 926-941. https://doi.org/10.1007/s10040-005-0009-9

Gosz, J.R., 1993. Ecotone hierarchies. Ecol. Appl. https://doi.org/10.2307/1941905

Griebler, C., Avramov, M., 2015. Groundwater ecosystem services: a review. Freshw. Sci. 34, 355-367. https://doi.org/10.1086/679903

Griebler, C., Malard, F., Lefébure, T., 2014. Current development in groundwater ecology - from biodiversity to ecosystem function and services. Curr. Opin. Biotechnol. 27, $159-167$.

Guilbeault, M. a, Parker, B.L., Cherry, J. a, 2005. Mass and flux distributions from DNAPL zones in sandy aquifers. Ground Water 43, 70-86. https://doi.org/10.1111/j.17456584.2005.tb02287.x

Hakenkamp, C.C., Palmer, M.A., James, B.R., 1994. Metazoans from a sandy aquifer: dynamics across a physically and chemically heterogeneous groundwater system. Hydrobiologia 287, 195-206.

Hoelen, T.P., Reinhard, M., 2004. Complete biological dehalogenation of chlorinated ethylenes in sulfate containing groundwater. Biodegradation 15, 395-403.

Hunkeler, D., Abe, Y., Broholm, M.M., Jeannottat, S., Westergaard, C., Jacobsen, C.S., Aravena, R., Bjerg, P.L., 2011. Assessing chlorinated ethene degradation in a large scale contaminant plume by dual carbon-chlorine isotope analysis and quantitative PCR. J. Contam. Hydrol. 119, 69-79. https://doi.org/10.1016/j.jconhyd.2010.09.009 
Hunkeler, D., Aravena, R., 2010. Investigating the origin and fate of organic contaminant in groundwater using stable isotope analysis, in: Aelion, C.M., Höhener, P., Hunkeler, D., Aravena, R. (Eds.), Environmental Isotopes in Biodegradation and Bioremediation. CRC Press, Boca Raton, Fla., p. 450.

Hunkeler, D., Morasch, B., 2010. Isotope fractionation during transformation processes, in: Aelion, C.M., Höhener, P., Hunkeler, D., Aravena, R. (Eds.), Environmental Isotopes in Biodegradation and Bioremediation. CRC Press, pp. 79-125.

IGC, 1996. Mapa Geològic de Catalunya 1:25.000.No. 258-1-2 (77-22): Navata. Institut Cartogràfic de Catalunya. Servei Geològic de Catalunya. Barcelona.

IGME, 1994. Mapa Geológico de España 1:50.000. No. 258: Figueres. Instituto Geológico y Minero de España, Madrid. Inst. Geológico y Min. España.

Johnston, D., 2006. Draft EPA guidelines regulatory monitoring and testing groundwater sampling, 56. 2006.

Kendall, C., Elliott, E.M., Wankel, S.D., 2008. Tracing Anthropogenic Inputs of Nitrogen to Ecosystems, in: Stable Isotopes in Ecology and Environmental Science: Second Edition. Blackwell Publishing, pp. 375-449. https://doi.org/10.1002/9780470691854.ch12

Kent, A.D., Smith, D.J., Benson, B.J., Triplett, E.W., 2003. Web-based phylogenetic assignment tool for analysis of terminal restriction fragment length polymorphism profiles of microbial communities. Appl. Environ. Microbiol. 69, 6768-6776.

Lendvay, J.M., Löffler, F.E., Dollhopf, M., Aiello, M.R., Daniels, G., Fathepure, B.Z., Gebhard, M., Heine, R., Helton, R., Shi, J., 2003. Bioreactive barriers: a comparison of bioaugmentation and biostimulation for chlorinated solvent remediation. Environ. Sci. Technol. 37, 1422-1431. 
Löffler, F.E., Sun, Q., Li, J., Tiedje, J.M., 2000. 16S rRNA gene-based detection of tetrachloroethene-dechlorinating Desulfuromonas and Dehalococcoides species. Appl. Environ. Microbiol. 66, 1369-1374.

Macbeth, T.W., Cummings, D.E., Spring, S., Petzke, L.M., Sorenson, K.S., 2004. Molecular characterization of a dechlorinating community resulting from in situ biostimulation in a trichloroethene-contaminated deep, fractured basalt aquifer and comparison to a derivative laboratory culture. Appl. Environ. Microbiol. 70, 73297341.

Malachowsky, K.J., Phelps, T.J., Teboli, a B., Minnikin, D.E., White, D.C., 1994. Aerobic mineralization of trichloroethylene, vinyl chloride, and aromatic compounds by rhodococcus species. Appl. Environ. Microbiol. 60, 542-8.

Mars, A., Houwing, J., 1996. Degradation of toluene and trichloroethylene by Burkholderia cepacia G4 in growth-limited fed-batch culture. Appl. ... 62, 886-891.

Maymó-Gatell, X., Chien, Y., Gossett, J.M., Zinder, S.H., 1997. Isolation of a bacterium that reductively dechlorinates tetrachloroethene to ethene. Science (80-. ). 276, $1568-1571$.

Maymó-Gatell, X., Tandoi, V., Gossett, J.M., Zinder, S.H., 1995. Characterization of an H2-utilizing enrichment culture that reductively dechlorinates tetrachloroethene to vinyl chloride and ethene in the absence of methanogenesis and acetogenesis. Appl. Environ. Microbiol. 61, 3928-3933.

McCarty, P.L., Semprini, L., Norris, R., Hinchee, R., Brown, R., Wilson, J., Kampbell, D., Reinhard, M., Bouwer, E., R., B., 1994. Ground-water treatment for chlorinated solvent, in: Handbook of Bioremediation. pp. 87-116.

McMahon, P.B., Chapelle, F.H., 2008. Redox processes and water quality of selected 
principal aquifer

systems.

Ground

Water

46, 259-71. https://doi.org/10.1111/j.1745-6584.2007.00385.x

McWorther, D.B., Kueper, B.H., 1996. Mechanics and mathematics of the movement of dense non-aqueous phase liquids (DNAPLs) in porous media, in: Dense Chlorinated Solvents and Other DNAPLs in Groundwater: History, Behavior, and Remediation. pp. 89-129.

Meckenstock, R.U., Morasch, B., Griebler, C., Richnow, H.H., 2004. Stable isotope fractionation analysis as a tool to monitor biodegradation in contaminated acquifers. J. Contam. Hydrol. 75, 215-55. https://doi.org/10.1016/j.jconhyd.2004.06.003

Mészáros, É., Sipos, R., Pál, R., Romsics, C., Márialigeti, K., 2013. Stimulation of trichloroethene biodegradation in anaerobic three-phase microcosms. Int. Biodeterior. Biodegradation 84 , 126-133. https://doi.org/10.1016/j.ibiod.2012.08.006

Moran, M.J., Zogorski, J.S., Rowe, B.L., 2006. Approach to an assessment of volatile organic compounds in the nation's ground water and drinking-water supply wells. Open-File Rep.

Murtagh, F., Legendre, P., 2011. Ward's Hierarchical Clustering Method: Clustering Criterion and Agglomerative Algorithm. arXiv:1111.6285.

Němeček, J., Dolinová, I., Macháčková, J., Špánek, R., Ševců, A., Lederer, T., Černík, M., 2017. Stratification of chlorinated ethenes natural attenuation in an alluvial aquifer assessed by hydrochemical and biomolecular tools. Chemosphere 184, 1157-1167. https://doi.org/10.1016/J.CHEMOSPHERE.2017.06.100

Nijenhuis, I., Kuntze, K., 2016. Anaerobic microbial dehalogenation of organohalides - state of the art and remediation strategies. Curr. Opin. Biotechnol. 
Nijenhuis, I., Nikolausz, M., Köth, A., Felföldi, T., Weiss, H., Drangmeister, J., Grossmann, J., Kästner, M., Richnow, H.-H., 2007. Assessment of the natural attenuation of chlorinated ethenes in an anaerobic contaminated aquifer in the Bitterfeld/Wolfen area using stable isotope techniques, microcosm studies and molecular biomarkers.

Chemosphere

67 , $300-11$. https://doi.org/10.1016/j.chemosphere.2006.09.084

Palau, J., Soler, A., Teixidor, P., Aravena, R., 2007. Compound-specific carbon isotope analysis of volatile organic compounds in water using solid-phase microextraction. J. Chromatogr. A 1163, 260-268.

Pankow, J.F., Cherry, J.A., 1996. Dense chlorinated solvents and other DNAPLs in groundwater: History, behavior, and remediation. Waterloo Press.

Pant, P., Pant, S., 2010. A review: Advances in microbial remediation of trichloroethylene (TCE). J. Environ. Sci. 22, 116-126. https://doi.org/10.1016/S1001-0742(09)600826

Puigserver, D., Carmona, J.M., Cortés, A., Viladevall, M., Nieto, J.M., Grifoll, M., Vila, J., Parker, B.L., 2013. Subsoil heterogeneities controlling porewater contaminant mass and microbial diversity at a site with a complex pollution history. J. Contam. Hydrol. $144,1-19$.

Puigserver, D., Herrero, J., Parker, B.L., Carmona, J.M., 2020. Natural attenuation of pools and plumes of carbon tetrachloride and chloroform in the transition zone to bottom aquitards and the microorganisms involved in their degradation. Sci. Total Environ. 712, 135679. https://doi.org/10.1016/j.scitotenv.2019.135679

Puigserver, D., Herrero, J., Torres, M., Cortés, A., Nijenhuis, I., Kuntze, K., Parker, B.L., 

Carmona, J.M., 2016. Reductive dechlorination in recalcitrant sources of chloroethenes in the transition zone between aquifers and aquitards. Environ. Sci. Pollut. Res. 23, 18724-18741. https://doi.org/10.1007/s11356-016-7068-4

Puls, R., Barcelona, M., 1996. Low-flow (minimal draw- down) ground-water sampling procedures. Off. Res. Dev. Off. Solid Waste Emerg. Response.

Rahm, B.G., Chauhan, S., Holmes, V.F., Macbeth, T.W., Kent Jr, S., Alvarez-Cohen, L., 2006. Molecular characterization of microbial populations at two sites with differing reductive dechlorination abilities. Biodegradation 17, 523-534.

Reij, M., Kieboom, J., 1995. Continuous degradation of trichloroethylene by Xanthobacter sp. strain Py2 during growth on propene. Appl. ... 61, 2936-2942.

Révész, S., Sipos, R., Kende, A., Rikker, T., Romsics, C., Mészáros, É., Mohr, A., Táncsics, A., Márialigeti, K., 2006. Bacterial community changes in TCE biodegradation detected in microcosm experiments. Int. Biodeterior. Biodegradation 58, 239-247.

Richardson, R.E., Bhupathiraju, V.K., Song, D.L., Goulet, T.A., Alvarez-Cohen, L., 2002. Phylogenetic characterization of microbial communities that reductively dechlorinate TCE based upon a combination of molecular techniques. Environ. Sci. Technol. 36, 2652-2662.

Russell, C., Jacobson, R., Haldeman, D., Amy, P., 1994. Heterogeneity of deep subsurface microorganisms and correlations to hydrogeological and geochemical parameters. Geomicrobiol. J. 12, 37-51.

Schaefer, C.E., Towne, R.M., Vainberg, S., McCray, J.E., Steffan, R.J., 2010. Bioaugmentation for treatment of dense non-aqueous phase liquid in fractured sandstone blocks. Env. Sci Technol. 44, 4958-4964. 
Semprini, L., 1995. In situ bioremediation of chlorinated solvents. Environ. Health Perspect. 103 Suppl, 101-5.

Shim, H., Ryoo, D., Barbieri, P., Wood, T.K., 2001. Aerobic degradation of mixtures of tetrachloroethylene, trichloroethylene, dichloroethylenes, and vinyl chloride by toluene- o-xylene monooxygenase of Pseudomonas stutzeri OX1. Appl. Microbiol. Biotechnol. 56, 265-269. https://doi.org/10.1007/s002530100650

Shyu, C., Soule, T., Bent, S.J., Foster, J.A., Forney, L.J., 2007. MiCA: a web-based tool for the analysis of microbial communities based on terminal-restriction fragment length polymorphisms of $16 \mathrm{~S}$ and $18 \mathrm{~S}$ rRNA genes. Microb. Ecol. 53, 562-70. https://doi.org/10.1007/s00248-006-9106-0

Silva, S.R., Kendall, C., Wilkison, D.H., Ziegler, A.C., Chang, C.C.Y., Avanzino, R.J., 2000. A new method for collection of nitrate from fresh water and the analysis of nitrogen and oxygen isotope ratios. J. Hydrol. 228, 22-36.

Sleep, B.E., Seepersad, D.J., Mo, K., Heidorn, C.M., Hrapovic, L., Morrill, P.L., McMaster, M.L., Hood, E.D., LeBron, C., Sherwood Lollar, B., Major, D.W., Edwards, E.A., 2006. Biological enhancement of tetrachloroethene dissolution and associated microbial community changes. Environ. Sci. Technol. Environmen, 3623-3633. https://doi.org/10.1021/es051493g

Stroo, H.F., Leeson, A., Marqusee, J.A., Johnson, P.C., Ward, C.H., Kavanaugh, M.C., Sale, T.C., Newell, C.J., Pennell, K.D., Lebrón, C.A., Unger, M., 2012. Chlorinated ethene source remediation: lessons learned. Environ. Sci. Technol. 46, 6438-47. https://doi.org/10.1021/es204714w

Tiehm, A., Schmidt, K.R., 2011. Sequential anaerobic/aerobic biodegradation of 
chloroethenes--aspects of field application. Curr. Opin. Biotechnol. 22, 415-21. https://doi.org/10.1016/j.copbio.2011.02.003

van der Zaan, B., Hannes, F., Hoekstra, N., Rijnaarts, H., de Vos, W.M., Smidt, H., Gerritse, J., 2010. Correlation of Dehalococcoides 16S rRNA and chloroethenereductive dehalogenase genes with geochemical conditions in chloroethenecontaminated groundwater. Appl. Environ. Microbiol. 76, 843-50. https://doi.org/10.1128/AEM.01482-09

Vannelli, T., Logan, M., Arciero, D.M., Hooper, A.B., 1990. Degradation of Halogenated Aliphatic Compounds by the ammonia- oxidizing bacterium Nitrosomonas europaea. Appl. Environ. Microbiol. 56.

Verce, M.F., Gunsch, C.K., Danko, A.S., Freedman, D.., 2002. Cometabolism of cis-1, 2-dichloroethene by aerobic cultures grown on vinyl chloride as the primary substrate. Environ. Sci. Technol. 36, 2171-2177.

Verce, M.F., Ulrich, R.L., Freedman, D.L., 2001. Transition from cometabolic to growthlinked biodegradation of vinyl chloride by a Pseudomonas sp. isolated on ethene. Environ. Sci. Technol. 35, 4242-51.

Vogel, T.M., Criddle, C.S., McCarty, P.L., 1987. ES Critical Reviews: Transformations of halogenated aliphatic compounds. Environ. Sci. Technol. 21, 722-36. https://doi.org/10.1021/es00162a001

Weatherill, J.J., Atashgahi, S., Schneidewind, U., Krause, S., Ullah, S., Cassidy, N., Rivett, M.O., 2018. Natural attenuation of chlorinated ethenes in hyporheic zones: A review of key biogeochemical processes and in-situ transformation potential. Water Res. 128, 362-382. https://doi.org/10.1016/J.WATRES.2017.10.059

Wei, N., Finneran, K.T., 2011. Influence of ferric iron on complete dechlorination of 
trichloroethylene (TCE) to ethene: Fe (III) reduction does not always inhibit complete dechlorination. Environ. Sci. Technol. 45, 7422-7430.

Wexler, S.K., Hiscock, K.M., Dennis, P.F., 2012. Microbial and hydrological influences on nitrate isotopic composition in an agricultural lowland catchment. J. Hydrol. 468469, 85-93. https://doi.org/10.1016/j.jhydrol.2012.08.018

Yang, Y., McCarty, P.L., 2002. Comparison between donor substrates for biologically enhanced tetrachloroethene DNAPL dissolution. Environ. Sci. Technol. 36, 34003404. https://doi.org/10.1021/es011408e

Yang, Y., McCarty, P.L., 2000. Biologically enhanced dissolution of tetrachloroethene DNAPL. Environ. Sci. Technol. 34, 2979-2984. https://doi.org/10.1021/es991410u

Zinder, S.H., 2016. The Genus Dehalococcoides, in: Organohalide-Respiring Bacteria. Springer Berlin Heidelberg, Berlin, Heidelberg, pp. 107-136. https://doi.org/10.1007/978-3-662-49875-0_6 